\title{
Strengthening Teacher's Work Ethic in Learning Through Academic Supervision Activities during the COVID-19 Pandemic Period in Sociology and Management Perspectives
}

\author{
Aep Saepuloh ${ }^{1}$, Ahmad Rusdiana ${ }^{2}$ \\ 1,2UIN Sunan Gunung Djati Bandung, Indonesia \\ Email: asaepuloh2007@uinsgd.ac.id
}

\begin{abstract}
Teachers have a very strategic role in advancing national education. Therefore, teachers work with a good work ethic. This study aims to analyze how the work ethic of teachers at Madrasah Ibtidaiyah Al-Mishbah Cipadung during the COVID-19 pandemic in learning through academic supervision activities. This research is a collaborative school action research conducted to improve and improve the quality of teachers in terms of learning work ethic, especially during the COVID-19 pandemic. The results of the pre-action research showed an average score of 64.42 , while in the first cycle the average score was 77.7 , while in the second cycle the average score was 85.86 . This means that there is a significant difference between the work ethic of teachers before and after academic supervision is carried out.
\end{abstract}

Keywords: Work Ethic, Teachers, Academic Supervision Activities.

\section{A. INTRODUCTION}

Professional Madrasah teachers during the COVID-19 pandemic have become a necessity. Urgent in terms of regulatory requirements and the demands of today's community needs. In terms of regulation, because the main task of teachers is as professional educators in Government Regulation Number 74 of 2008 in Chapter I, Article 1, Paragraph (1) it is stated that: Teachers are professional educators with the main task of educating, teaching, guiding, directing, training, assessing, and evaluating students in early childhood education through formal education, basic education, and secondary education (Carso, 2021). In terms of the demands and expectations of the community, teachers are expected to inspire and be able to help eliminate obstacles in the way. It is known that at this time we together have responded that the Covid-19 pandemic is not only an obstacle, but also a challenge to be able to accelerate the ability to carry out technology-based education.

Contrasting with the theme of World Teachers' Day 2020, which reads "Teachers: Leading in Crisis, Organizing Indonesia's Future" is very relevant to current conditions. When education enters an era of distribution, Indonesia is undergoing various very challenging dynamics of life. This challenge has changed people's way of life in working, interacting, including changes in the way of thinking and acting in carrying out education. Contemporary dynamics presents the 
need for the existence of teachers as critical leaders in managing the future. This dynamic leads us to reaffirm our awareness that adaptation to the strategic environment is a substantial matter. And presenting technology in education is a fundamental part (Ali, 2020).

In this context, the position of the teacher plays a very important and main role. "Ing Ngarso Sung Tulodo, Ing Madyo Mangun Karso, Tut Wuri Handayani" Teachers need to appear as dynamic and critical figures as a necessity in managing the life of a nation. The figure of the teacher must be able to act as a leader who serves as an example, inspiration, motivator, facilitator and catalyst. In times of crisis due to the current pandemic, the presence of teachers is very necessary to inspire the formation of a strong human figure, namely a human being who is able to respond to limited conditions while maintaining self-consistency to always have quality in preparing the nation's future. That's where the teacher's performance becomes the focus and hope.

Work will certainly have the goal of achieving results in the form of objects, works or services to the community. In humans there are needs that in time will be able to form the goals to be achieved. The goals to be achieved are not only related to the physical, but also to the mental (soul) such as self-recognition, satisfaction, achievement, and others. Achieving goals at work requires a strong work ethic (Carso, 2021).

Based on the Webster Dictionary (2007), defines ethos as a belief that serves as a guide to the behavior of a person, group, or institution. So, work ethic can be interpreted as a doctrine about work that is believed by a person or group of people about good and right which is manifest specifically in their work behavior (Pratana \& Ferryal, 2018).

Harsono \& Santoso (2006), stated that work ethic is a work spirit based on certain values or norms. This is in accordance with the opinion of Sukriyanto (2000) which states that work ethic is a work spirit possessed by a person or society in order to be able to work better in order to obtain added value in life. So that this work ethic is able to determine human judgment that is manifested in a job.

Ethos is a view of life that is typical of a social group (KBI, 2008). The National Encyclopedia of Indonesia, mentions the word ethos as the basic character of a society. Furthermore, ethos is defined as the ability to solve a problem or problem at hand. It includes a way of looking at all the problems it faces. For example, about the perspective of world affairs, education, work and others (Nata, 2001).

In terms, experts provide different (various) meanings. Frans Magnis Suseno for example, he called ethos as a consistent inner attitude of a person or group of people in which there is moral pressure and certain moral values. Clifford Gertez defines ethos as an attitude that is fundamental to the self and the world that life radiates. Thus, the ethos concerns the spirit of life, including the spirit of work, studying, building and improving skills so that they can live better in the future (Tebba, 2003). 
The ethos was further formulated by David Mc. Clelland with the term mental virus that is driven to live a successful life which is then abbreviated in the term Need for Achievement which means the encouragement of the need to achieve success or a better achievement than before. Clelland further emphasized that ethos is closely related to efforts or actions to do something better from time to time that has been done more efficiently, faster, saves energy with satisfactory results (Carso, 2021).

Work is all activities that are carried out because of the urge to make something happen and are carried out on purpose so that a great sense of responsibility grows to produce quality works or products. Work ethics are attitudes, views, habits, characteristics or traits regarding the way a person, a group or a nation works (Marosa, 2019). A high work ethic certainly will not make you bored, even able to improve achievement or performance. Things that have high work ethics include the desire to uphold the quality of work, then individuals who have a work ethic will also provide input in the workplace.

The teacher's work ethic is the behavior of motivation and intelligence that becomes a positive work group, a professional way of working, and noble character both inside and outside the teacher's workspace. Work ethic refers more to personality qualities that are carried out through full performance in various dimensions of life (Carso, 2021).

Thus, work ethic is more of an internal condition behavior that encourages and controls workers towards the realization of ideal work quality. Professionalism is the commitment of members of a profession to continuously improve their abilities and have a cultural system that is able to provide satisfying services for those who are served. Professionalism is the attitude of a professional, and professional means doing something as a main job called a profession, meaning that the work is not a free time filler or a mere hobby. If the profession is defined as work and ism as a way of life, then professionalism can be defined as thinking, standing, thinking and working hard, working full time, discipline, high loyalty and full dedication to work success.

The main task of teachers is as professional educators in Government Regulation Number 74 of 2008 concerning Teachers in Chapter I, Article 1, Paragraph (1), it is emphasized that: Teachers are professional educators with the main task of educating, teaching, guiding, directing, training, assessing, and students in early childhood education, formal education, basic education, and secondary education (Government Regulation of the Republic of Indonesia Number 7 of 2008 concerning Tearhers).

For that matter, several studies show: first; research conducted by. First; Vida Astutiningsih (2011), The Relationship between Work Ethic and Professional High School Teachers. The results of this study state: 1) There is a very significant positive relationship between work ethic and professional high school teachers. 2) The contribution of work ethic to professional teachers is 0.679 or $67.9 \%$. This means that there are still $32.1 \%$ of several other variables such as work motivation, 
support from coworkers, work environment, and conflict at work. 3) The level of the subject's professional attitude is moderate. 4) The level of the subject's work ethic is high.

Second; research conducted by Yuyun et al. (2013), regarding the influence of the principal's leadership style and teacher work ethic on teacher performance, it is found that the teacher's work ethic has a significant effect on teacher performance, so it can be said that an increase in the teacher's work ethic will also lead to high teacher performance, and vice versa if the work ethic If the teacher decreases, the teacher's performance will also decrease. The work ethic of the teacher is very influential on the performance of the teacher himself because the work ethic of the teacher is an attitude that arises of his own will and awareness which is based on a system of cultural value orientation towards work.

Third; research conducted by Wiratama et al. (2013) This study aims to determine and analyze several phenomena in the field such as teachers who do not pursue their profession professionally in terms of working outside of their working hours, are less able to take advantage of free time opportunities for creativity, can affect the performance of junior high school teachers in the District. Looks siren. The results showed that there was a significant contribution of professional attitude to the performance of State Junior High School teachers in Tampaksiring District by $26.5 \%$. There is a significant contribution of teacher work ethic to the performance of State Junior High School teachers in Tampaksiring District of $15.6 \%$. There is a significant contribution of work climate to the performance of State Junior High School teachers in Tampaksiring District by $15.6 \%$. There is a significant contribution between professional attitudes, teacher work ethic, and work climate on the performance of State Junior High School teachers in Tampaksiring District by $54.2 \%$

On that basis, the "work ethic" has the basis of cultural values, which of these cultural values form the work ethic of each individual that is able to influence the performance of the individual himself. In this study, because the correlation value between teacher performance and teacher work ethic is greater than the correlation value between teacher performance and the principal's leadership style, the work ethic variable has more influence on teacher performance than the principal's leadership style variable. This happens because the teacher's work ethic is more related to the teacher's personality so that it affects the teacher's performance more than the leadership style of the principal who is different from the teacher. So from the several studies above, there is a directly proportional relationship between work ethic and teacher professionalism and teacher performance. So if a teacher has a high work ethic, the professionalism and performance of the teacher will be high, and vice versa.

Teachers have a very strategic role in advancing national education. Therefore, teachers work with a good work ethic. However, in reality, it is known, based on the results of performance of teachers at MI Al-Mishbah Cipadung Bandung has not been encouraging (Usep, 2021). This condition requires academic 
supervision to be carried out. Academic supervision is professional assistance to teachers, through a cycle of systematic planning, careful observation, and immediate and objective feedback. that way the teacher can use the feedback to pay attention to his performance. The main objective of academic supervision is to improve the professional abilities of teachers and improve the quality of learning through good learning. The purpose of academic supervision is to develop a better teaching and learning situation through coaching and improving the teaching profession (Carso, 2021).

Conceptually, academic supervision aims to empower professional accountability, in an effort to improve the teaching and learning process of teachers, and to help teachers develop their abilities in achieving student learning goals. In this case, the supervisor provides professional coaching. Academic supervision is a series of coaching activities with the objectives of: (1) increasing the effectiveness and efficiency of the learning process; (2) supervising the quality of learning, (3) developing teacher professionalism, and 4) motivating teachers. Furthermore, Priansa (2014:108) explains that academic supervision is carried out in order to help teachers (1) plan lessons; (2) presenting learning materials; (3) evaluate learning; (4) managing the class; (5) developing curriculum; (6) evaluate the curriculum; (7) selfevaluating; and (8) working together in groups (Faturrohman, 2011; Hamzah, 2014; Priansa, 2014; and Sola, 2019).

The success of the implementation of education in madrasas cannot be separated from the role of supervisors, madrasa heads and teachers. The main task of the teacher is to teach and help students solve learning problems and their personal and social development. The principal of the madrasa leads teachers and students in the learning process and helps overcome the problems they face. Supervisors supervise and provide assistance to principals, teachers and students in overcoming problems encountered during the education process. The essence of the purpose of academic supervision is to develop better teaching and learning situations. What is meant by teaching and learning situations is a situation where there is a process of interaction between teachers and students in an effort to achieve the specified learning goals. Efforts towards improving learning are aimed at achieving the ultimate goal of education, namely the formation of independent children (Wahyudi, 2009).

\section{B. METHOD}

This research was conducted at Madrasah Ibtidaiyah (MI) Al-Misbah Cipadung, Bandung City, West Java Province, Indonesia. This research is a collaborative school action research conducted to improve and improve the quality of teachers in learning work ethic. Action research generally includes the use of research models and the collection of qualitative and interpretive data from educators/teachers (Denzin \& Yvonna, 2009). Collaborative supervisory action research or Participatory Action Research (PAR) is carried out in collaboration between the principal and the researcher. 
In PAR, three special characteristics are often used that make it different from conventional research, namely the shared responsibility for the research project, community-based analysis and an orientation towards community action (Denzin \& Lincoln, 2009). The model used in this study is the research model expressed by Kemmis and Taggart which is the development of Kurt Lewin's model. This model can cover several cycles and in each cycle includes the following stages: (1) planning; (2) acting and observing or implementing and observing; (3) reflecting or reflection; (4) revise plan or plan revision.

In this study using observation techniques. Observation is the basis of all knowledge. Scientists can only work based on data, namely facts about the real world obtained through Nasution's observations (Sugiyono, 2005). According to Marshall (Sugiyono, 2005), it was explained that "through observation, the researcher learned about behavior and he meaning attached to those behavior". Through observation, researchers learn about behavior and the meaning of that behavior. Observations or observations are made on the process of implementing academic supervision to measure the work ethic of teachers in learning. Documentation in this research can be in the form of photos or videos about what is done during academic supervision. While the portfolio is related to the teacher's task of compiling the syllabus, lesson plans, and preparation of teaching materials.

Data analysis in this study used qualitative and quantitative descriptive analysis techniques. Calculation of quantitative data is to calculate the average child development based on the scores obtained from the observation sheets that have been prepared previously. With the average obtained, it can be seen the percentage of development of the ability of serialization in children. Data analysis using qualitative descriptive techniques utilizing percentages is just the first step of the whole analysis process by Arikunto (2010). The percentage expressed in numbers is clearly a quantitative measure, not qualitative. So the percentage statement is not the result of a qualitative analysis. Qualitative analysis of course must be stated in a predicate that refers to a state statement, a measure of quality.

\section{RESULT AND DISCUSSION}

In principle, the implementation of the first cycle has been going well, but it is necessary to improve the sharing culture so that there are more visible collaborative activities. The results of the first cycle are as follows:

\section{Table 1 Results of Cycle I}

\begin{tabular}{|c|c|c|c|c|c|c|c|c|c|c|c|c|c|c|c|c|c|c|c|c|c|c|c|c|c|}
\hline \multirow{2}{*}{ RES. } & \multicolumn{25}{|c|}{ SKOR BUTIR } \\
\hline & 1 & 2 & 3 & 4 & 5 & 6 & 7 & 8 & 9 & 10 & 11 & 12 & 13 & 14 & 15 & 16 & 17 & 18 & 19 & 20 & 21 & 22 & 23 & 24 & $\mathrm{JML}$ \\
\hline 1 & 4 & 3 & 3 & 2 & 4 & 2 & 4 & 4 & 4 & 2 & 2 & 2 & 2 & 4 & 3 & 4 & 4 & 3 & 2 & 2 & 3 & 3 & 2 & 3 & 71 \\
\hline 2 & 3 & 3 & 4 & 4 & 3 & 2 & 3 & 3 & 3 & 3 & 3 & 2 & 3 & 3 & 3 & 4 & 4 & 3 & 4 & 3 & 3 & 4 & 4 & 4 & 78 \\
\hline 3 & 3 & 3 & 4 & 4 & 3 & 3 & 3 & 3 & 2 & 2 & 2 & 2 & 4 & 4 & 4 & 4 & 4 & 2 & 4 & 4 & 3 & 4 & 4 & 4 & 79 \\
\hline 4 & 4 & 2 & 4 & 2 & 3 & 3 & 2 & 3 & 2 & 2 & 4 & 4 & 4 & 3 & 2 & 3 & 2 & 4 & 4 & 4 & 4 & 2 & 4 & 4 & 75 \\
\hline 5 & 3 & 4 & 4 & 4 & 2 & 3 & 2 & 3 & 2 & 4 & 2 & 3 & 2 & 3 & 4 & 4 & 3 & 3 & 4 & 4 & 4 & 4 & 2 & 4 & 77 \\
\hline 6 & 3 & 3 & 4 & 3 & 3 & 4 & 4 & 3 & 3 & 4 & 2 & 2 & 3 & 3 & 3 & 4 & 3 & 4 & 4 & 4 & 3 & 3 & 4 & 4 & 80 \\
\hline 7 & 4 & 4 & 4 & 4 & 3 & 4 & 3 & 3 & 4 & 4 & 3 & 3 & 4 & 4 & 4 & 1 & 4 & 3 & 4 & 3 & 3 & 4 & 4 & 3 & 84 \\
\hline
\end{tabular}


Source: Processed by Researcher

The table above shows the average score of 77.7 with a standard deviation of 4.07 and the data is normally distributed. From these results the researchers arranged the second cycle for improvement.

In principle, the implementation of cycle II has been going well, and it was fun. The results of the second cycle are as follows:

Table 2 Results of Cycle2

\begin{tabular}{|c|c|c|c|c|c|c|c|c|c|c|c|c|c|c|c|c|c|c|c|c|c|c|c|c|c|}
\hline \multirow{2}{*}{ RES. } & \multicolumn{25}{|c|}{ SKOR BUTIR } \\
\hline & 1 & 2 & 3 & 4 & 5 & 6 & 7 & 8 & 9 & 10 & 11 & 12 & 13 & 14 & 15 & 16 & 17 & 18 & 19 & 20 & 21 & 22 & 23 & 24 & $\mathrm{JML}$ \\
\hline 1 & 4 & 3 & 4 & 2 & 4 & 2 & 4 & 4 & 4 & 4 & 4 & 2 & 4 & 4 & 3 & 4 & 4 & 3 & 4 & 4 & 3 & 3 & 2 & 4 & 83 \\
\hline 2 & 3 & 3 & 4 & 4 & 3 & 4 & 4 & 4 & 4 & 3 & 3 & 2 & 3 & 3 & 3 & 4 & 4 & 3 & 4 & 3 & 3 & 4 & 4 & 4 & 83 \\
\hline 3 & 4 & 3 & 4 & 4 & 4 & 4 & 4 & 3 & 2 & 2 & 2 & 2 & 4 & 4 & 4 & 4 & 4 & 4 & 4 & 4 & 4 & 4 & 4 & 4 & 86 \\
\hline 4 & 4 & 4 & 4 & 2 & 4 & 4 & 4 & 3 & 4 & 4 & 4 & 4 & 4 & 3 & 2 & 3 & 2 & 4 & 4 & 4 & 4 & 2 & 4 & 4 & 85 \\
\hline 5 & 4 & 4 & 4 & 4 & 4 & 4 & 4 & 3 & 4 & 4 & 4 & 3 & 2 & 3 & 4 & 4 & 3 & 3 & 4 & 4 & 4 & 4 & 4 & 4 & 89 \\
\hline 6 & 4 & 4 & 4 & 3 & 3 & 4 & 4 & 3 & 3 & 4 & 4 & 4 & 3 & 3 & 3 & 4 & 3 & \begin{tabular}{|l|}
4 \\
\end{tabular} & 4 & 4 & 3 & 3 & 4 & 4 & 86 \\
\hline 7 & 4 & 4 & 4 & 4 & 3 & 4 & 3 & 3 & 4 & 4 & 4 & 4 & 4 & 4 & 4 & 4 & 4 & 3 & 4 & 3 & 3 & 4 & 4 & 3 & 89 \\
\hline
\end{tabular}

Source: Processed by Researcher

The table above shows the average score of 85.86 with a standard deviation of 2.49 and the data is normally distributed. From these results, the researcher assessed that the second cycle had exceeded the achievement indicators.

From each cycle there has been an average increase. As for measuring whether there is a difference between cycles I and II, a t-test was conducted which was preceded by a data homogeneity test. With SPSS homogeneity test the data is presented as follows:

Table 3 Homogeneity Test Cycle I and II ANOVA

\begin{tabular}{|l|r|r|r|r|r|}
\hline & $\begin{array}{c}\text { Sum of } \\
\text { Squares }\end{array}$ & df & Mean Square & F & Siq. \\
\hline Between Groups & 49.929 & 3 & 16.643 & 1.009 & .497 \\
Within Groups & 49.500 & 3 & 16.500 & & \\
Total & 99.429 & 6 & & & \\
\hline
\end{tabular}

Source: Processed by Researcher

The table states that the sig is $0.497>0.05$ so the data is homogeneous. Then the test was carried out, with the help of SPSS the following results were obtained:

Table 4 t-Test Results Paired Samples Test

\begin{tabular}{|c|c|c|c|c|c|c|c|c|}
\hline & \multicolumn{5}{|c|}{ Paired Differences } & \multirow[b]{3}{*}{$t$} & \multirow[b]{3}{*}{$d$} & \multirow[b]{3}{*}{ Sio. $(2$ taleo) } \\
\hline & \multirow[b]{2}{*}{ Mean } & \multirow[b]{2}{*}{ Str. Deviation } & \multirow{2}{*}{$\begin{array}{c}\text { Std. Eror } \\
\text { Mean } \\
\end{array}$} & \multicolumn{2}{|c|}{$\begin{array}{l}\text { 95\% Confidence Irterval of the } \\
\text { Diference }\end{array}$} & & & \\
\hline & & & & Loner & Uoper & & & \\
\hline Pair1 VAR00002-VAR00003 & -8.14286 & 313202 & 1.18379 & -11.03949 & -5224623 & -6.879 & 6 & .000 \\
\hline
\end{tabular}

Source: processed by researcher

From the table above, the probability value or sig (2-tailed) is $0.000<0.05$, 
meaning that there is a significant difference in the work ethic of teachers before and after academic supervision is carried out.

\section{CONCLUSION}

Based on the results of the study, it can be concluded that the process of academic supervision to improve the work ethic of teachers was carried out twice. The supervision activities for cycles I and II involved 7 teachers and madrasah principals. From the pre-action, cycle I, and cycle II, there are differences in the average culture of the teacher's work ethic. Pre-action data showed an average score of 64.42 , while in the first cycle the average score was 77.7 , while in the second cycle the average score was 85.86 . This proves that there is a significant difference in the work ethic of teachers before and after academic supervision is carried out.

\section{ACKNOWLEDGMENTS}

The researcher expresses gratitude to the leadership of Madrasah Ibtidaiyah (MI) AlMishbah Cipadung Bandung who has facilitated this research and we express our gratitude to the students and teachers of MI Al-Mishbah Cipadung Bandung who were very helpful in completing this research.

\section{REFERENCES}

1. Anoraga, P. (2001). Psikologi Kerja. Jakarta: Rineka Cipta.

2. Arikunto, S. (2010). Prosedur Penelitian Suatu Pendekatan Praktek. Jakarta: Rineka Cipta.

3. Astutiningsih, V. (2011). Hubungan antara Etos Kerja dengan Profesional Guru SMA (Skripsi Fakultas Psikologi Universitas Muhammadiyah Surakarta).

4. Carso, C. (2021). Penguatan Etos Kerja Guru dalam Pembelajaran Melalui Kegiatan Supervisi Akademik. ARJI: Action Research Journal Indonesia, 3(1), 10-18.

5. Denzin, N. K., \& Lincoln, Y. S. (2009). Handbook of Qualitative Research. Yogyakarta: Pustaka Pelajar.

6. Fajriani, Y., \& Santoso, S. (2013). Pengaruh gaya kepemimpinan kepala sekolah dan etos kerja guru terhadap kinerja guru (studi pada al-azhar syifa budi solo). Jupe-Jurnal Pendidikan Ekonomi, 1(1), 1-11.

7. Government Regulation of the Republic of Indonesia Number 74 of 2008 concerning Teachers.

8. Harsono, J., \& Santoso, S. (2006). Etos Kerja Pengusaha Muslim Perkotaan di Kota Ponorogo. Jurnal Penelitian Humaniora, 2(1), 115-125.

9. Massora, A. (2020). Pengaruh Etika Kerja dan Komitmen Organisasi Terhadap Kinerja Pegawai Kementerian Pariwisata. Jurnal Manajemen FE-UB, 7(1), 14-28.

10. Muhaimin, Ali, N., Suti'ah, \& Azizah, S. L. (2004). Paradigma Pendidikan Islam: Upaya mengefektifkan pendidikan agama Islam di sekolah. Remaja Rosdakarya.

11. Nata, A. (2001). Paradigma Pendidikan Islam: Kapita Selekta Pendidikan Islam. Jakarta: Grasindo.

12. Nitisemito, A. (2001). Manajemen Sumber Daya Manusia. Jakarta: Grasindo. 
13. Oktafiani, A. (2010). Hubungan Gaya Kepemimpinan Kepala Sekolah dengan Etos Kerja Guru di MAN Cibinong. (Skripsi Jurusan MPI UIN Syarif Hidayatullah).

14. Pratana, A., \& Abadi, F. (2018). Analisis Pengaruh Etos Kerja, Hubungan Kerja dan Pengembangan Karir Terhadap Komitmen Organisasional Berdampak Pada Kinerja Karyawan. Jurnal Ikraith Ekonomika, 1(2), 83-92.

15. Ramdani, A. (2020). Tema Hari Guru Sedunia Relevan Dengan Kondisi Saat Ini "Tag. Guru Penggerak, 08 Oktober 2020". Retrieved from: http://pgdikmen.kemdikbud.go.id/read-news

16. Sola, E. (2019). Supervisi Akademik versus Kualitas Pembelajaran. Jurnal Idaarah, 3(1), 148-154.

17. Sudjana, N. (2009). Penilaian Hasil Proses Belajar Mengajar. Bandung: Remaja Rosdakarya.

18. Sukiyanto. (2020). Etos Kerja Salah Satu Faktor Survivalitas Peternak Sapi Perah, Studi Kasus di Desa Sidomulyo, Kecamatan Batu Kota Batu Kabupaten Malang. (Thesis Program Pasca Sarjana UMM).

19. Sumidjo, W. (2002). Kepemimpinan Kepala Sekolah. Jakarta: Raja Grafindo Persada.

20. Tebba, S. (2003). Membangun Etos Kerja Dalam Persfektif Tasawuf. Bandung: Pustaka Nusantara.

21. Tim Pusat Bahasa. (2008). Kamus Bahasa Indonesia. Jakarta: Pusat Bahasa Diknas.

22. Usep. (2021). Penilaian kinerja guru di MIS Al-Mishbah Cipadung Bandung tahun ajaran 2020/2021.

23. Wahyudi. (2009). Kepemimpinan Kepala Sekolah dalam Organisasi Pembelajar Learning Organnization. Bandung: Alfabeta.

24. Wiratama, A., Candiasa, I. M., \& Yudana, M. (2013). Kontribusi Sikap Profesional, Etos Kerja dan Iklim Kerja Terhadap Kinerja Guru SMP Negeri di Kecamatan Tampaksiring. Jurnal Administrasi Pendidikan Indonesia, 4(1). 